\title{
Periampullary Duodenal Diverticulum with Phytobezoar and Choledocholithiasis
}

\section{Divertículo Duodenal Periampular com Fitobezoar Associado a Coledocolitíase}

\author{
João Abrantes ${ }^{1}$, Artur Antunes², Clara Fernandes ${ }^{1}$, João Granadeiro1
}

KEYWORDS: Bezoars; Biliary Tract Diseases; Choledocholithiasis; Diverticulum

PALAVRAS-CHAVE: Bezoares; Coledocolitíase; Divertículo; Doenças Biliares

\section{MANUSCRIPT}

The patient presented with recurrent epigastric pain and recent onset jaundice, with laboratory findings showing anemia $(10.5 \mathrm{~g} / \mathrm{dL})$ and increased bilirubin levels (3.40 mg/dL).

Abdominal and pelvic computed tomography (CT) scan Fig. 1 showed a saccular outpouching arising from the medial wall of the $2^{\text {nd }}$ part of duodenum near the ampulla, replete with gas and non-enhancing contents with mottled gas pattern, corresponding to a periampullary duodenal diverticulum with endoluminal phytobezoar. Coronal reformatted images (Fig. 2) demonstrated radiopaque biliary calculi in the lumen of the dilated common bile duct (choledocholithiasis).

Periampullary duodenal diverticula (PAD) represents duodenal extraluminal diverticula located in the vicinity (around 2-3 cm) of the ampulla of Vater and are thought to be acquired because of the anatomical characteristics of the periampullary region predisposing to the diverticular development. ${ }^{1}$

The association of biliary tract disease and PAD is proven in all age groups above 40 years of age, with higher incidence of choledocholithiasis. Other non-biliary complications of duodenal diverticula are reported, such as diverticulitis, diverticular bleeding, diverticular perforation and obstructive jaundice (Lemmel's syndrome). ${ }^{2-3}$

A phytobezoar is a concretion of poorly digested fibers and can be an uncommon cause of small bowel obstruction that can uncommonly be primarily formed in the small intestine, especially if associated with underlying small bowel diseases such as diverticula. ${ }^{4}$

In CT and magnetic resonance (MR) studies, the extraluminal diverticula appear as a focal outpouching filled 


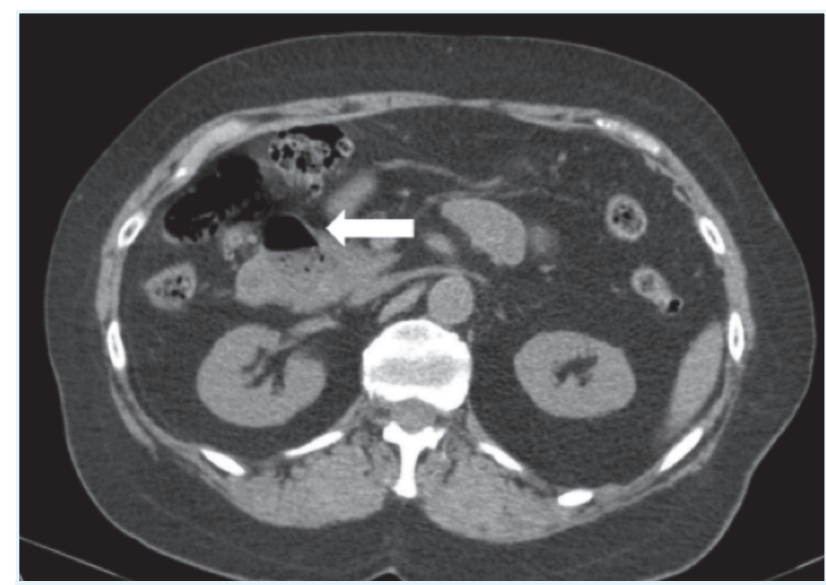

FIGURE 1. Computed tomography revealing a duodenal diverticulum arising from the medial wall of the $2^{\text {nd }}$ part of duodenum (white arrow), with gas and solid content with mottled gas pattern (phytobezoar).

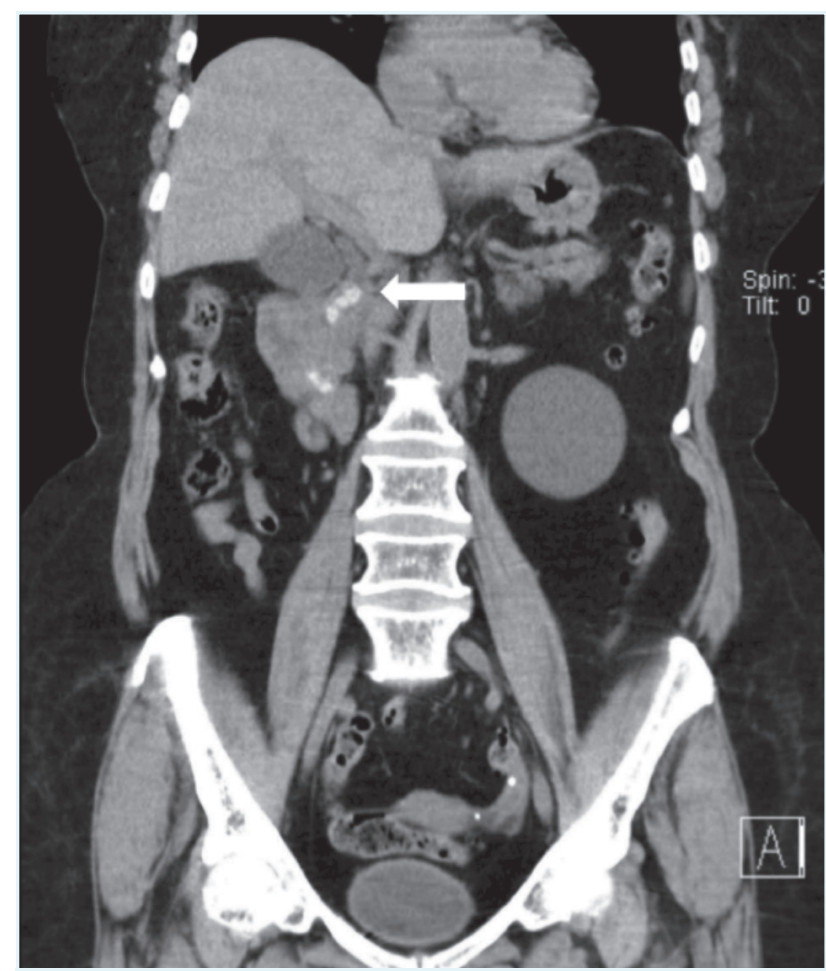

FIGURE 2. Reformatted coronal abdominal and pelvic computed tomography depicting the presence of multiple radiopaque coledocolithiasis (white arrow) and mild dilatation of the extra-hepatic bile duct.

with gas-fluid/contrast or debris, adjacent to the normal duodenal lumen. Phytobezoars are usually depicted in $\mathrm{CT}$ as an ovoid mass containing mottled gas pattern. ${ }^{5}$

Endoscopic evaluation confirmed a duodenal diverticulum with an endoluminal phytobezoar obstructing the access to the major papilla and impeding the cannulation of the biliary duct. Treatment of these cases presents a challenge, and an endoscopic retrograde cholangiopancreatography (ERCP) rendezvous procedure was performed after elective surgical exploration and cholecystectomy, with guidewire guidance. ${ }^{6}$ Choledocholithiasis removal was possible after sphincterotomy was performed.
CONFLICTS OF INTEREST: The authors declare that they have no conflicts of interest.

FINANCIAL SUPPORT: This work has not received any contribution, grant or scholarship.

CONFIDENTIALITY OF DATA: The authors declare that they have followed the protocols of their work center on the publication of data from patients.

CONFLITOS DE INTERESSE: Os autores declaram não ter qualquer conflito de interesse na realização do presente trabalho.

FONTES DE FINANCIAMENTO: Não houve qualquer fonte de financiamento na realização do presente trabalho.

CONFIDENCIALIDADE DOS DADOS: Os autores declaram ter seguido os protocolos da sua instituição acerca da publicação dos dados de doentes.

\section{REFERENCES}

1. Suda K, Mizuguchi K, Matsumoto M. A histopathological study on the etiology of duodenal diverticulum related to the fusion of the pancreatic anlage. Am J Gastroenterol. 1983;78:335-8.

2. Osnes M, Løotveit T, Larsen S, Aune S. Duodenal diverticula and their relationship to age, sex, and biliary calculi. Scand J Gastroenterol. 1981;16:103-7.

3. Naranjo-Chavez J, Schwarz M, Leder G, Beger HG. Ampullary but not periampullary duodenal diverticula are an etiologic factor for chronic pancreatitis. Dig Surg. 2000;17:358-63. doi: 10.1159/000018879.

4. Frazzini VI, English WJ, Bashist B, Moore E. Case report. Small bowel obstruction due to phytobezoar formation within Meckel diverticulum: CT findings. J Comput Assist Tomogr. 1996;20:390-2.

5. Bittle MM, Gunn ML, Gross JA, Rohrmann CA. Imaging of duodenal diverticula and their complications. Curr Probl Diagn Radiol. 2012;41:20-9. doi: 10.1067/j.cpradiol.2011.07.001.

6. Odabasi M, Yildiz MK, Abuoglu HH, Eris C, Ozkan E, Gunay E, Aktekin A, Muftuoglu MT. A modified Rendezvous ERCP technique in duodenal diverticulum. World J Gastrointest Endosc. 2013;5:568. doi: 10.4253/wjge.v5.i11.568. 